\title{
Analisis Terapi Lintah (Hirudotherapy) di Rumah Sehat Klasik Bekasi Utara
}

\author{
Syafira Soraya $^{1 *}$, Tantry Agnhitya Sari ${ }^{1}$, Shafa Noer ${ }^{1}$ \\ ${ }^{I}$ Prodi Pendidikan Biologi, Fakultas MIPA, Universitas Indraprasta PGRI \\ *email: syafirasoraya4@gmail.com
}

Article History
Received:
24/03/2021
Revised:
20/04/2021
Accepted:
05/05/2021

Kata kunci:

Terapi lintah Hirudotherapy Lintah

\begin{abstract}
ABSTRAK
Masyarakat Indonesia yang tingkat kemajemukannya tinggi dengan beragam kultur budaya, membawa pengaruh terhadap beragamnya metode pengobatan. Salah satu pengobatan tradisional yang ada saat ini yaitu pengobatan tradisional dengan menggunakan media lintah sebagai penyembuh penyakitnya. Sejak dahulu hingga kini, pemanfaatan lintah medis (Hirudo medicinalis) sebagai pengobatan atau dikenal dengan terapi lintah, menjadi perhatian masyarakat. Terapi lintah sudah mulai banyak diaplikasikan di Indonesia saat ini. Bahkan, tidak sedikit masyarakat yang mengandalkan terapi lintah secara rutin sebagai tindakan preventif atau merawat kesehatan. Penelitian ini bertujuan untuk menganalisis metode pengobatan terapi lintah di Rumah Sehat Klasik Bekasi Utara. Penelitian ini dilakukan dari bulan Maret 2019 hingga bulan Juli 2019. Metode pengumpulan data dilakukan dengan menggunakan observasi, wawancara, dan dokumentasi (triangulasi). Penelitian ini menggunakan metode kualitatif deskriptif. Hasil dari penelitian ini menunjukkan bahwa metode pengobatan terapi lintah memiliki peluang kesembuhan yang tinggi untuk berbagai jenis indikasi penyakit terapi lintah. Hal ini dikarenakan lintah mengandung banyak zat yang penuh manfaat bagi tubuh manusia. Hasil analisis terapi lintah ini menunjukkan bahwa terapi lintah baik sebagai tindakan preventif dan pengobatan penyakit.
\end{abstract}

Key word: Leech theraphy Hirudotherapy Leech

\section{ABSTRACT}

Indonesian society with a high level of diversity with a variety of cultural cultures has influenced the variety of treatment methods. One of the traditional treatments that exist today is traditional medicine using leeches as a cure for the disease. Sinc e ancient times until now, the use of medical leeches (Hirudo medicinalis) for treatment, or better known as leech therapy, has attracted the attention of the public. Leech therapy has begun to be widely applied in Indonesia today. In fact, not a few people rely on regular leech therapy as a preventive action or health care. This study aims to analyze the method of leech therapy treatment in Classic Healthy Homes Bekasi Utara. This research was conducted from March 2019 to July 2019 at Classic Healthy Homes, Central Kaliabang, Bekasi Utara. The data collection technique is done by using observation, interview, and documentation (triangulation) techniques. The data analysis technique used descriptive qualitative analysis. The results of this study found that the leech therapy treatment method has a high chance of cure for various types of leech therapy disease indications. This is because leeches contain many substances that are full of benefits to the human body. The results of the analysis of leech therapy show that it is good for health prevention and treatment of disease.
\end{abstract}

\section{Copyright $@ 2021$ LPPM Universitas Indraprasta PGRI. All Right Reserved}

\section{PENDAHULUAN}

Sistem pengobatan modern telah berkembang pesat dimasa sekarang ini dan telah menyentuh hampir semua lapisan masyarakat seiring dengan majunya ilmu pengetahuan, teknologi, kedokteran, farmasi, dan sebagainya. Dewasa ini, praktikpraktik pengobatan medis modern telah berkembang baik, yakni pengobatan medis yang diselenggarakan oleh lembaga pemerintah maupun swasta selalu diikuti dengan perkembangan praktik-praktik pengobatan tradisional. Hal ini menunjukkan bahwa eksistensi pengobatan tradisional terbilang cukup baik serta menjadi model pengobatan alternatif masyarakat Indonesia.

Masyarakat Indonesia yang tingkat kemajemukannya tinggi dengan beragam kultur budaya, membawa pengaruh terhadap beragamnya metode pengobatan. Selain metode pengobatan dalam dunia kedokteran modern, terdapat juga 
metode pengobatan tradisional. Sebagaimana dijelaskan pada pasal 12 ayat (1) dan (2) Keputusan Menteri Kesehatan Nomor 1076 Tahun 2003 tentang enyelenggaraan pengobatan tradisional, dinyatakan bahwa pengobatan tradisional merupakan salah satu upaya pengobatan dan/atau perawatan cara lain diluar ilmu kedokteran dan/atau ilmu keperawatan, sebagai upaya peningkatan kesehatan, pencegahan penyakit, penyembuhan penyakit, dan/atau pemulihan kesehatan (Menkes, 2003).

Data dari SUSENAS (Survey Sosial Ekonomi Nasional) menyatakan bahwa pada tahun 2001 hingga 2011, masyarakat Indonesia melakukan pengobatan tradisional semakin meningkat sebesar $49.53 \%$ dari $9.8 \%$ (Rahayu, 2012). Data dari SUSENAS menunjukkan bahwa sistem pengobatan alternatif cukup berkembang di masyarakat Indonesia. Perkembangan pengobatan tersebut didorong oleh beberapa faktor, diantaranya faktor sosial, faktor ekonomi, faktor budaya, faktor psikologis, faktor kejemuan terhadap pelayanan atau fasilitas medis, faktor manfaat dan keberhasilan, faktor pengetahuan, dan pemahaman tentang sakit, dan penyakit (Assegaf, 2011).

Sistem pengobatan tradisional dapat menjadi pilihan alternatif bagi masyarakat untuk menjadi jalur penyembuhan pengobatan suatu penyakit. Berkenaan dengan jalur pengobatan, secara umum masyarakat mengenal dua pilihan yaitu jalur medis (metode kedokteran) dan jalur non medis (metode tradisional). Kini, keduanya sama-sama dibutuhkan adanya. Namun, pengobatan modern yang telah berkembang dimasa sekarang ini merupakan sistem pengobatan dengan menggunakan obat dari bahan kimia sintesis, dimana penggunaan obat-obat sintesis tersebut kurang baik untuk dikonsumsi dalam jangka panjang, karena memiliki efek samping yang dapat merusak hati dan ginjal jika digunakan dalam jangka waktu yang lama.

Kegagalan dan disharmoni pada sistem pengobatan modern seringkali menjadi faktor penting masyarakat dalam pelimpahan usaha pengobatan dan pemulihannya ke pengobatan alternatif. Hal ini dibuktikan adanya 15\% pengaduan dengan total 543 penggunaan obat dari periode waktu Januari-Juli tahun 2012. Tercatat 63\% pengaduan dari 890 layanan kesehatan di Yayasan Pemberdayaan Konsumen Kesehatan Indonesia (YPKKI) terhadap layanan medis, antara lain berupa biaya pengobatan yang tinggi, penggunaan perlengkapan kesehatan yang ilegal, obat kadarluarsa, dan malpraktik (YPKKI, 2012).
Berdasarkan hasil studi pendahuluan melalui wawancara kepada masyarakat Bekasi Utara, mayoritas masyarakatnya berusaha mencari dan beralih pengobatan alternatif yang menjadi pilihan untuk menyelesaikan masalah kesehatannya. Akhir-akhir ini mulai banyak bermunculan klinikklinik pengobatan tradisional yang sangat diminati oleh masyarakat luas. Seperti halnya mayoritas di wilayah Bekasi Utara, salah satu tempat pengobatan alternatif masyarakat Bekasi Utara yaitu di Rumah Sehat Klasik yang terletak di daerah Perumahan Alinda, Kaliabang Tengah, Bekasi Utara.

Salah satu pengobatan tradisional yang ada saat ini yaitu pengobatan tradisional dengan menggunakan media lintah sebagai penyembuh penyakitnya. Sejak dahulu hingga kini, pemanfaatan lintah medis (Hirudo medicinalis) sebagai pengobatan, atau saat ini dikenal dengan terapi lintah, menjadi perhatian masyarakat dalam memilih teknik pengobatan. Terapi lintah sudah mulai banyak diaplikasikan di Indonesia saat ini. Bahkan, tidak sedikit masyarakat yang mengandalkan terapi lintah secara rutin sebagai tindakkan preventif atau merawat kesehatan.

Terapi lintah adalah suatu jenis terapi dengan memanfaatkan hisapan lintah. Hakikatnya, teknik pengobatan dengan mengisap darah sebagai pengobatan dan juga melancarkan aliran darah atau dengan istilah bekam dan fashdu, hanya berbeda pada medianya yaitu lintah. Salah satu khasiat yang paling popular adalah mengobati peradangan, meringankan nyeri, hingga melancarkan peredaran darah. Manfaat lainnya yaitu untuk mengobati abses, artritis, glaukoma, miastenia gravis, thrombosis, dan beberapa kelainan vena. Selain manfaat yang telah disebutkan di atas, lintah medis ini juga dapat digunakan sebagai operasi plastik dan beberapa masalah sirkulasi darah lainnya serta penyakit jantung iskemik (Taqiyyah \& Anggraini, 2017). Penelitian ini memiliki tujuan yaitu untuk menganalisis metode pengobatan terapi lintah di Rumah Sehat Klasik Bekasi Utara.

\section{METODE PENELITIAN}

Penelitian ini dilaksanakan pada bulan Maret 2019 hingga bulan Juli 2019. Penelitian ini dilakukan dengan proses yang bertahap yaitu mulai dari tahap perencanaan, persiapan penelitian yang dilanjutkan dengan pengumpulan data lapangan sebagai kegiatan inti penelitian, dan diakhiri dengan laporan penelitian. Penelitian dilakukan di Rumah Sehat Klasik Jalan Alinda No. 95, Kaliabang Tengah, Bekasi Utara. 
Penelitian ini menggunakan metode kualitatif deskriptif. Hal ini dikarenakan, penelitian dilakukan pada kondisi yang alamiah. Data yang ingin diperoleh dari penelitian ini yakni mengenai analisis terapi lintah di Rumah Sehat Klasik. Penelitian ini menggunakan teknik sampling berupa purposive sampling. Adapun sampel/subjek yang dipilih merupakan pasien yang sedang melakukan terapi di Rumah Sehat Klasik yakni sebanyak 15 orang.

Metode yang digunakan dalam penelitian ini adalah metode triangulasi. Peneliti menggunakan wawancara terstruktur dan berkembang, observasi, dan dokumentasi untuk sumber data yang sama secara bersamaan. Teknik analisis data dalam penelitian ini dilakukan dengan tiga cara, yaitu reduksi data, penyajian data, dan penarikan kesimpulan.

\section{HASIL PENELITIAN}

\section{Karakteristik Responden Penelitian}

Berdasarkan data sekunder (dokumen) dari 15 responden, diketahui bahwa pasien di Rumah Sehat Klasik yang berusia <40 tahun lebih banyak dibandingkan dengan pasien yang memiliki usia lebih dari 40 tahun. Pada tingkat pendidikan responden di Rumah Sehat Klasik, sebagian besar lulusan SMA/sederajat sebanyak 9 orang, sedangkan tingkat pendidikan yang paling sedikit adalah lulusan SMP/ sederajat, $\mathrm{SD} /$ sederajat, dan pasien yang tidak menempuh pendidikan sebanyak masing-masing 1 orang. Perbandingan pasien yang menjalani terapi yakni pasien laki-laki lebih banyak dibandingkan pasien perempuan. Pada pasien bermata pencaharian pokok sebagai karyawan swasta sebanyak 6 orang, sebagai wiraswasta sebanyak 2 orang, sebagai ibu rumah tangga sebanyak 3 orang, sebagai Pegawai Negeri Sipil (PNS) sebanyak 1 orang, sebagai pengajar sebanyak 1 orang, dan sebagai mahasiswa sebanyak 2 orang.

\section{Standar Operasional Terapi Lintah}

Hasil wawancara dengan beberapa pasien bahwa mereka dapat memahami dan menerima semua Standar Operasional Prosedur (SOP) yang diberikan dan dilakukan terapis Rumah Sehat Klasik. Setelah memahami semua SOP, beberapa pasien berpendapat bahwa pelayanan yang diberikan lebih terstruktur dan terpercaya serta merasa yakin bahwa tindakkan terapi menjadi salah satu upaya pengobatan.
Tabel 1. Frekuensi karakteristik responden penelitian

\begin{tabular}{|c|c|}
\hline Karakteristik & Jumlah \\
\hline \multicolumn{2}{|l|}{$\overline{\text { Umur }}$} \\
\hline 19-30 tahun & 6 \\
\hline 31-40 tahun & 4 \\
\hline $41-50$ tahun & 2 \\
\hline$>65$ tahun & 3 \\
\hline \multicolumn{2}{|l|}{ Jenis Kelamin } \\
\hline Laki-laki & 9 \\
\hline Perempuan & 6 \\
\hline \multicolumn{2}{|l|}{ Pendidikan Terakhir } \\
\hline Tidak sekolah/tidak tamat SD & 1 \\
\hline SD/MI/sederajat & 1 \\
\hline SMP/MTS/sederajat & 1 \\
\hline SMA/sederajat & 9 \\
\hline Perguruan Tinggi & 3 \\
\hline \multicolumn{2}{|l|}{ Jenis Pekerjaan } \\
\hline Karyawan & 6 \\
\hline Wiraswasta & 2 \\
\hline Ibu rumah tangga & 3 \\
\hline PNS & 1 \\
\hline Pengajar & 1 \\
\hline Mahasiswa & 2 \\
\hline \multicolumn{2}{|l|}{ Analisis Penyakit } \\
\hline Kolesterol & 2 \\
\hline Vertigo & 1 \\
\hline Darah tinggi & 2 \\
\hline Alergi & 2 \\
\hline Stroke & 2 \\
\hline Asma & 1 \\
\hline Saraf kejepit & 1 \\
\hline Insomnia & 1 \\
\hline Pasca operasi & 1 \\
\hline Pasca kecelakaan & 1 \\
\hline Jerawat & 1 \\
\hline Total & 15 \\
\hline
\end{tabular}

\section{Mutu Pelayanan Terapi}

Hasil data kuesioner yang diisi oleh pasien setelah terapi dan wawancara dengan pasien, bahwa mutu atau kualitas yang diberikan oleh Rumah Sehat Klasik memperoleh nilai dan anggapan baik dari pasien. Selain itu, pasien juga mengakui saat diwawancarai oleh peneliti yaitu pelayanan yang baik inilah menjadikan pasien untuk rutin terapi tanpa mempersoalkan biaya yang akan dikeluarkan.

Penilaian yang diberikan pasien terhadap mutu atau kualitas Rumah Sehat Klasik melalui pengisian kuesioner memiliki tinjauan beberapa aspek penilaian, yaitu aspek pelayanan terapi lintah, aspek fasilitas, aspek perhatian/empati, aspek edukasi, aspek pelayanan administrasi, dan aspek biaya. Sebagaimana tinjauan dari aspekaspek tersebut terlihat pada kuesioner yang termuat 
dalam lampiran, mayoritas pasien menilai atau memberikan tanggapan dengan alternatif jawaban yaitu sangat baik dan baik.

\section{Edukasi pada Pasien}

Hasil wawancara dari beberapa pasien, mereka berpendapat bahwa penjelasan yang diberikan terapis mengenai terapi lintah sangat mudah dipahami dan sangat membantu kelengkapan informasi yang diperoleh. Hal ini terutama dirasakan oleh pasien baru dimana dengan kesabaran terapis dan keyakinan pasien terhadap terapi lintah, pasien tetap mengikuti edukasi terapi lintah yang diberikan Rumah Sehat Klasik.

\section{Informasi yang Diperoleh Pasien Mengenai Terapi Lintah}

Penuturan pasien yang berkunjung untuk melakukan terapi lintah, yaitu mayoritas dari pasien mengetahui metode pengobatan terapi lintah melalui testimoni kerabat dekat dan tetangga yang pernah melakukan terapi lintah, namun ada beberapa dari pasien yang mengetahuinya dari internet atau buku. Selain itu, peneliti menjumpai tiga pasien yang direkomendasikan langsung oleh terapis untuk terapi lintah karena ditinjau dari penyakit yang diderita pasien yaitu darah tinggi dan eksim yang tak kunjung sembuh meski sudah menjalani metode pengobatan konvensional lainnya seperti bekam, totok darah, ataupun akupuntur.

\section{Ketertarikan dan Minat Pasien Terhadap Terapi Lintah}

Salah satu faktor alasan pasien Rumah Sehat Klasik memilih metode pengobatan terapi lintah sebagai jalur penyembuhan pengobatan suatu penyakit. Sebagaimana hasil wawancara peneliti dengan pasien, ketertarikan pasien terhadap metode pengobatan terapi lintah tidak hanya karena masalah ekonomi (biaya), namun peluang kesembuhan penyakit hampir $70 \%$ berhasil, bahkan ada yang mengatakan peluang kesembuhan mencapai $95 \%$ setelah 3 kali terapi lintah.

Pasien yang pertama kali melakukan terapi lintah, ketertarikannya terhadap terapi lintah berasal dari testimoni seseorang, internet, maupun buku. Melalui informasi-informasi mengenai terapi lintah itulah menyebabkan pasien yang belum pernah menjadi tertarik dan ada minat untuk melakukan terapi lintah.

\section{Persepsi Pasien Pada Saat atau Setelah Terapi}

Sebagaimana penuturan pasien yang berkunjung untuk melakukan terapi lintah pada bagian wajah dengan keluhan jerawat. Meskipun sudah dua kali terapi, pasien tetap merasakan sensasi kesetrum pada saat lintah mulai menggigit, begitupun ketika lintah sudah menempel dan menghisap, pasien merasakan sensasi hisapan serta sedikit rasa sakit. Hal ini lebih dirasakan terlebih ketika lintah melepaskan gigitannya, pasien merasakan sedikit perih pada bekas gigitan lintah, namun setelah luka ditutup kassa, rasa perih pertama kali melakukan terapi lintah. Meskipun ada beberapa pasien menuturkan bahwa banyaknya aturan dan prosedur yang diberikan terapis, namun sedikit berkurang dan akan hilang ketika tidak ada lagi pendarahan atau luka mengering.

Berbeda halnya penuturan pasien yang berkunjung untuk melakukan terapi lintah pada bagian kaki dengan keluhan eksim. Pasien dengan keluhan eksim di bagian kaki ini, sudah melakukan tiga kali terapi, ia hanya merasakan gigitan lintah seperti gigitan semut saja.

\section{Pendapat atau Kepuasan Pasien}

Melalui pengisian kuesioner dan wawancara, beberapa pasien berpendapat bahwa pelayanan kesehatan dari segi administrasi Rumah Sehat Klasik sudah cukup baik dan puas terhadap proses pelayanan yang diberikan yakni tepat, cepat, dan tidak berbelit-belit. Pelayanan kesehatan dari segi edukasi, semua pasien menanggapi pelayanan edukasi dengan alternatif jawaban baik dan sangat baik. Pelayanan kesehatan berikutnya yaitu dari segi metode terapi lintah, beberapa pasien menuturkan bahwasannya mereka puas akan layanan yang diberikan, terlebih pada saat lintah melepas gigitannya karena sudah cukup darah, terapis sangat terampil dalam menangani pendarahan pasca terapi, mulai dari membersihkan darah yang keluar sampai penutupan luka dengan kassa, dilakukan dengan rapi dan bersih. Pelayanan kesehatan selanjutnya yaitu dari segi fasilitas, penuturan pasien yang berkunjung untuk melakukan terapi lintah, yaitu fasilitas yang ada di Rumah Sehat Klasik sudah cukup baik, ruang terapi tertata rapi, bersih, nyaman, dan siap pakai, memiliki alat-alat terapi yang higienis, dan tersedia juga obat-obat herbal. Adanya fasilitas-fasilitas dan pelayanan yang baik, pasien merasa puas, nyaman, dan akan kembali lagi berkunjung untuk melakukan terapi di Rumah Sehat Klasik. Pelayanan kesehatan yang terakhir yaitu dari segi 
biaya terapi lintah, hasil wawancara peneliti dengan pasien mengenai pengeluaran biaya untuk terapi lintah yaitu pasien tidak mempermasalahkan mengenai biaya karna biaya yang ditawarkan Rumah sehat klasik cukup terjangkau dan terkadang Rumah Sehat Klasik memberikan potongan harga kepada pasien.

\section{PEMBAHASAN}

Sejak awal penggunaan lintah medis $(H$. medicinalis) hingga kini, masih menjadi perhatian masyarakat dalam pemilihan teknik pengobatan alternatif. Rahasianya yaitu ada pada air liur lintah yang banyak mengandung obat untuk berbagai penyakit.

Sarasi (2011) menjelaskan yakni pada saat ini terapi lintah sudah banyak diaplikasikan di Indonesia, terutama sebagai salah satu terapi secara islami (Thibbun Nabawi). Terapi lintah berkembang di Indonesia berawal dari pengiriman delegasi ke Malaysia untuk mempelajari terapi pengobatan dengan menggunakan lintah (hirudotherapy).

Indonesia merupakan salah satu negara yang mempercayai terapi lintah sebagai pengobatan alternatif dalam menyembuhkan masalah kesehatan. Namun tidak semua jenis lintah dapat digunakan sebagai terapi, sebagaimana Sarasi (2011) menjelaskan secara lengkap jenis lintah yang dapat diaplikasikan sebagai pengobatan terapi, yakni yang telah teridentifikasi kurang lebih sekitar 600 jenis lintah, namun yang dapat digunakan hanya sekitar 15 jenis sebagai pengobatan. Lintah di sini merupakan "lintah medis" yang sejak berabad-abad telah diplikasikan oleh para terapis, terutama di negara wilayah Eropa dan Amerika. Dahulu, diperkirakan hanya ada satu jenis lintah medis yang memiliki warna berbeda, yakni $H$. medicinalis dan $H$. officinalis. Namun, berdasarkan penelitian ilmiah, dari perbedaan pola permukaan tubuh lintah, terbukti menandakan adanya dua jenis lintah medis yang berbeda, yakni $H$. medicinalis dan $H$. verbana, yang dapat diuji dengan analisis DNA. Kedua jenis lintah selama ini tidak pernah dibedakan, karena keduanya digunakan secara bersamaan dan tidak ada perbedaan pada aktivitas dan komposisi air liurnya.

Hal ini dikarenakan lintah mengandung banyak zat yang penuh manfaat bagi tubuh manusia. Sebagaimana penjelasan Hayes (2004), bahwa para ilmuan terus meneliti keunikan lintah, terutama pada air liurnya. Air liur lintah mampu mencegah atau menghentikan pembekuan darah diyakini bisa memberikan manfaat lebih bagi manusia suatu saat nanti.

Pendapat Hayes (2004) diperjelas dengan pernyataan Taqiyyah \& Anggraini (2017) bahwa saat lintah diaplikasi pada kulit, lintah akan menggigit dan mengeluarkan saliva yang menginduksi anestesi lokal dan vasodilatasi sehingga lintah mulai menghisap darah. Beberapa substansi akan dilepaskan untuk mencegah proses pembekuan darah yaitu hirudin yang merupakan inhibitor trombin alami dengan efek paling kuat. Tabel 2. memperlihatkan kandungan zat pada air liur lintah dan fungsinya.

Tabel 2. Kandungan air liur H. medicinalis

\begin{tabular}{ll}
\hline Kandungan Zat & \multicolumn{1}{c}{ Fungsi Kandungan Zat } \\
\hline \multirow{3}{*}{ Hirudin } & $\begin{array}{l}\text { Zat aktif dalam ludah sekresi } \\
\text { kelenjar lintah, berfungsi } \\
\text { sebagai antikoagulan ampuh } \\
\text { (Pengencer darah). } \\
\text { Menghambat pembekuan darah } \\
\text { dengan mengikat thrombin. }\end{array}$ \\
\hline Hyaluronidase & $\begin{array}{l}\text { Memfasilitasi penetrasi dan } \\
\text { difusi aktif secara farmakologi } \\
\text { zat ke dalam jaringan, terutama } \\
\text { di nyeri sendiri dan memiliki } \\
\text { sifat antibiotik. }\end{array}$ \\
\hline Colin & $\begin{array}{l}\text { Menghambat pembekuan darah } \\
\text { dengan menghalangi pengikat } \\
\text { faktor kolagen. }\end{array}$ \\
\hline Bdellins & $\begin{array}{l}\text { Anti-inflamasi efek dan } \\
\text { menghambat tripsin, plasmin } \\
\text { dan acrocin. }\end{array}$ \\
\hline Anesthetic & $\begin{array}{l}\text { Mengurangi rasa sakit selama } \\
\text { lintah menggigit. }\end{array}$ \\
\hline Histamine & $\begin{array}{l}\text { Meningkatkan masuknya darah } \\
\text { di lokasi gigitan }\end{array}$ \\
\hline Sumber Abdulah
\end{tabular}

Sumber: Abdullah et al. (2012)

Berdasarkan paparan data di atas, terapi lintah memiliki banyak manfaat, baik untuk preventif kesehatan maupun penyembuhan penyakit. Hal ini memiliki persamaan dalam hal hasil penelitian dengan data di atas. Berdasarkan wawancara dengan pasien yang telah menjalani terapi lintah, baik yang baru pertama kali ataupun yang sudah beberapi terapi lintah, sebanyak 15 orang, menyatakan bahwa terapi lintah ini bagus untuk preventif kesehatan maupun pengobatan penyakit. Melalui pelayanan terapi lintah ini, masyarakat sangat terbantu dalam hal pengobatan alternatif. Selain itu, Rumah Sehat Klasik memiliki terapis yang ahli dalam praktek terapi lintah dan memiliki fasilitas yang cukup baik dan memadai.

Pada segi layanan, pasien sangat puas dengan layanan yang diberikan Rumah Sehat Klasik, sebab Rumah Sehat Klasik memiliki standar pelayanan 
kesehatan yang menjadi mutu atau kualitas pelayanan kesehatan, sehingga dapat mempengaruhi kepuasan pasien terhadap pelayanan yang diberikan Rumah Sehat Klasik. Kepuasan pasien adalah salah satu indikator keberhasilan pemberian pelayanan kesehatan kepada masyarakat, sehingga setiap instansi kesehatan memiliki standar kepuasan pelayanan kesehatan masing-masing.

Oleh karena itu, menurut Umar (2005) mengenai kepuasan konsumen atau pelanggan, salah satunya adalah meningkatnya persepsi konsumen melaui harapannya setalah melakukan perbandingan. Jika seorang pelanggan merasakan kepuasan dengan memberikan nilai produk atau jasa yang diperoleh, maka sangat besar kemungkinan akan menjadi pelanggan dalam waktu lama. Adapun aspek yang memengaruhi kepuasan pelanggan yakni kualitas produk dan pelayanannya.

Hasil observasi yang telah dilakukan, peneliti mendapatkan berbagai informasi, baik mengenai instansi kesehatan Rumah Sehat Klasik maupun mengenai metode pengobatan terapi lintah. Hasil observasi mengenai informasi instansi kesehatan, Rumah Sehat Klasik memiliki SOP tersendiri dalam pengelolaan tempat terapi, managemen, marketing internal maupun eksternal, serta keutamaan dalam standar alat terapi dan logistik yang dipakai. Hal ini menunjukkan bahwa SOP Rumah Sehat Klasik cukup baik, memiliki peralatan yang steril dan logistik yang akan digunakan sangat diperhatikan, terutama dalam pemilihan hewan lintah untuk digunakan terapi, karena pasien yang datang untuk terapi bukan hanya sekadar untuk preventif kesehatan, tetapi juga pasien yang sakit, dan kemungkinan dapat menularkan penyakit.

Hasil observasi mengenai informasi metode pengobatan terapi lintah yang dipakai oleh Rumah Sehat Klasik sudah sesuai dan memenuhi standar instansi kesehatan dengan langkah-langkah terapi sebagai berikut:

1) Mengambil lintah dengan menggunakan sarung tangan atau tissue.

2) Menentukan titik bagian tubuh yang menjadi tempat lintah untuk menggigit.

3) Menusukkan jarum pada titik bagian tubuh guna mengeluarkan darah agar lintah mudah untuk mengisap.

4) Mengarahkan ujung yang lebih kecil (kepala) ke bagian tubuh yang akan diterapi, kemudian bagian belakang lintah atau ekor (ujung bagian besar) akan menempel di sekitarnya.
5) Menutup lintah dengan tissue untuk menyerap air yang keluar dari tubuh lintah.

6) Memantau terus lintah untuk memastikan lintah tidak berpindah tempat.

7) Jika lintah sudah terisi dengan cukup darah, biasanya lintah jatuh dengan sendirinya. Jika tidak, gunakan garam, minyak kayu putih, parfume, atau sesuatu yang memiliki bau yang menyengat dan arahkan ke kepalanya.

8) Meletakkan lintah ke dalam bejana yang berisikan air.

9) Setelah lintah lepas, letakkan tissue atau gulungan pembalut untuk menyerap darah yang keluar.

10) Menutup luka bekas gigitan menggunakan kain kassa yang sebelumnya sudah diberi sedikit bubuk kopi atau sedikit robekan dari daun bandotan guna menghentikan pendarahan di kulit akibat gigitan lintah.

11) Terakhir, merekatkan kain kassa menggunakan plester.

Hasil pengamatan yang telah didapat, sesuai dengan penjelasan Atmoko (2011) bahwa SOP adalah suatu panduan atau dasar dalam melakukan tugas pekerjaan sesuai dengan kegunaan dan instrumen penilaian kinerja instansi pemerintah berlandaskan parameter teknis, administratif, dan kebijakan sesuai tata kerja, prosedur kerja, dan prosedur kerja terhadap bidang kerja yang berkaitan.

\section{KESIMPULAN}

Berdasarkan hasil penelitian dan pembahasan mengenai analisis terapi lintah (Hirudotherapy) di Rumah Sehat Klasik Bekasi Utara, maka diperoleh kesimpulan bahwa metode pengobatan terapi lintah memiliki peluang kesembuhan yang tinggi untuk berbagai jenis indikasi penyakit terapi lintah. Pengobatan alternatif di Rumah Sehat Klasik memiliki SOP tersendiri dalam pengelolaan tempat terapi, managemen, marketing internal maupun eksternal, serta keutamaan dalam standar alat terapi dan logistik yang digunakan. Mutu pelayanan terapi yang diberikan Rumah Sehat Klasik memiliki tanggapan yang baik dari pasien dan pasien pun merasa puas akan layanan yang diberikan selama terapi berlangsung.

\section{DAFTAR PUSTAKA}

Abdullah, S., Dar, L. M., Rashid, A., \& Tewari, A. (2012). Hirudotherapy/leech therapy: applications and indications in surgery. 
Archives of Clinical Experimental Surgery, 1(3), 172-180. https://doi.org/ 10.5455/aces.20120402072447.

Assegaf, S. H. (2011). Hubungan Tingkat Pengetahuan dengan Perilaku Minum Obat Antibiotik Golongan Sefalosporin pada Pasien Rawat Jalan Penyakit Infeksi Saluran Pernafasan Akut di Apotek. Skripsi. Universitas Muhammadiyah Malang.

Atmoko, T. (2011). Standar Operasional Prosedur (SOP) dan Akuntabilitas Kinerja Instansi Pemerintah. Universitas Padjajaran: Bandung.

Hayes, S. C. (2004). Acceptance and Commitment Therapy and The New Behavior Therapies: Mindfulness, Acceptance and Relationship. In Hayes, S. C., Follette, V. M., \& Linehan, M. (Eds.) Mindfulness and Acceptance: Expanding the Cognitive Behavioral Tradition (pp. 1-29). Guilford: New York.
Peraturan Menteri Kesehatan Republik Indonesia No. 1076 Tahun 2003 tentang Penyelenggaraan Pengobatan Tradisional. 2003. Menkes: Jakarta.

Rahayu, D. A. (2012). Faktor-faktor yang Berhubungan dengan Pemilihan Pengobatan Tradisional di Wilayah Kerja Puskesmas Muara Siberut Kecamatan Siberut Selatan Kabupaten Kepulauan Mentawai Tahun 2012. Skripsi. Universitas Andalas.

Sarasi V. (2011). Terapi Lintah Teori dan Praktek. http://www.academia.edu/5258016/Terapi_Li ntah_Teori_Dan_Praktek_Pengalaman_dan_p enelitian_Dokter_praktisi_dan_ahli_biologi_J erma n. Diakses tanggal 23 Januari 2021.

Taqiyyah I., \& Anggraini, D. I. (2017). Terapi lintah sebagai alternatif pengobatan pada dermatitis atopik. Medula, 7(5), 171-176.

Umar, H. (2005). Study Kelayakan Bisnis. 3th Ed. Gramedia Pustaka Utama: Jakarta. 